\title{
THE EFFECT OF ORGANIZATIONAL CULTURE AND EMPOWERMENT TO THE SERVICE QUALITY OF GENERAL BUREAU EMPLOYEES AT THE MINISTRY OF STATE SECRETARIAT REPUBLIC OF INDONESIA
}

\author{
Haryono $\mathrm{K}^{*}$, Eryanto $\mathrm{H}$ and Wibowo \\ State University of Jakarta Indonesia and \\ University Prof. Dr Moestopo, Jakarta Indonesia
}

\begin{abstract}
Service quality is very important for every institution, especially the government institutions. However, the service quality of General Bureau employees at the Ministry of State Secretariat was not optimal. This is known by the fact that the services provided are not in accordance with the expectations and the service standard. Therefore, this research was conducted by researchers, to find out what variables can affect service quality. Based on the results of quantitative analysis, it is known that service quality is influenced by several variables, including organizational culture and empowerment. The purpose of this quantitative comparative-correlational research, using survey method, is to reveal the effects of organizational culture and empowerment in correlated to general bureau quality services, directly or indirectly, and to determine appropriate strategies to improve the quality of service. Data was gathered from 76 employees of the General Bureau at the Ministry of State Secretariat Republic of Indonesia. In the result of the research revealed that (1) the culture of an organization has a direct impact towards the quality of a service, (2) empowerment gives a direct positive impact on service quality, (3) culture of an organization also gives a direct impact on empowerment, (4) the culture of an organization through empowerment results a positive impact on service quality. It can be concluded that the variable that directly affects service quality is the variable of organizational culture with a path coefficient of 0.322 , it means that an increasement in organizational culture will cause an increase in service quality. This study examines the quality of service and the factors that influence it from the variables of organizational culture dan empowerment that has never been done before both in the sample, research location and the methods used by the researcher. The results showed that a significant model for improving the quality of employee services at the General Bureau was by improving organizational culture, and the empowerment as an intervening variable.
\end{abstract}

Keywords: Organization Culture, Empowerment, Service Quality, Employee Performance, General Bureau

\section{Introduction}

In Bourini, et.al's research entitled "Investigating the managerial practices' effect on EmployeePerceived Service Quality with the moderating role of supportive leadership behavior" explains that service quality is the very important thing in making customer satisfaction, in this case, the leader and all customers, both internal and external of the organization. By giving an optimal service, hopefully, the organization will achieve its targets and goals easier. (Bourini et al., 2019). 
Based on the observations and surveys of previous researchers in 2018, there are some problems that related to the service quality, such as some of the services are not finish at the allotted time, the employees look untidy and impolite while giving the services, lack of coordination between divisions, unequal assignments to the employees, and sometimes, services are only carried out in operational working hours. (Haryono, 2018)

The Ministry of State Secretariat has a very strategic role in supporting the fluency of the duties and functions of the President and Vice President in running the government, which is led by the Minister of State Secretary, In carrying out his duties, the Minister of State Secretary is supported by the state civil apparatus that supports administrative and protocol tasks. (Kementerian Sekretariat Negara RI, 2015)

Based on the Minister of State Secretary Regulation Number 3, 2015 about the Organization and Work Procedure in the Ministry of State Secretariat, one of the existing Bureaus of the State Secretariat specialized in providing support for household services is the General Bureau. Based on the observations and interviews conducted, it is known that there are still several problems in the General Bureau especially in the service quality. (Kementerian Sekretariat Negara RI, 2015)

In 2018, a researcher found out that it is known that there are several factors that are affect the service quality of General Bureau employees of the State Secretariat, such as work motivation, supervision, organizational culture, education and training, empowerment, work engagement, work environment, compensation and employee rotation. (Haryono, 2018)

Kuldip Singh's research, entitled Influence of Internal Service Quality on Job Performance: A Case Study of the Royal Police Department, stated that the quality of internal services is positively related with job performance publik (Kuldip Singh, 2016). This study shows that the quality of internal services has a positive correlation with the police personnel performance.

Dean. A. Koutroumanist, in his research entitled Leadership Paradigms, Generational Differences, And Cultural Norms and Their Effects on Service Quality in The Restaurant Industry, added that developing human resources will increase various aspects of work and employee satisfaction which is positively related to customer satisfaction and loyalty and finally will affect the organizational performance. (Koutroumanis \& Dixon, 2018).

Considering the urgency of the problem in this study, the researcher limits the research to factors of organizational culture, and empowerment which assumed will affect the service quality.

\section{Literature Review}

According to Groetsh and Davis, as stated by Hardiyansyah that "The quality of a service is a dynamic condition that is related to product, service process and its surroundings which fulfills or meets beyond expectations" (Hardiyansyah, 2011). A quality is something that is related to a fulfillment or customers' expectations.

Lewis and Booms in Fandi Tjiptono added that a quality service is defined as "How perfect a service level given could result according to customers' expectations" (Tjiptono, 2008). Based on this statement, service quality is determined by the ability of an organization or institution to fulfill 
customers' needs and aspiration based on their expectation or hope. In short, it can be concluded that Lewis and Booms agree with the statement given by Groets and Davis Barata, A. A. (2014). Dasardasar Pelayanan Prima; Persiapan Membangun Budaya Pelayanan Prima untuk Meningkatkan Kepuasan dan Loyalitas Pelanggan. Jakarta: Gramedia.

Bourini, I., Jahmani, A., Mumtaz, R., \& Al-Bourini, F. A. (2019). Investigating the managerial practices' effect on Employee-Perceived Service Quality with the moderating role of supportive leadership behavior. European Research on Management and Business Economics, 25(1), 8-14. https://doi.org/10.1016/j.iedeen.2018.11.001

Gefagnoli, J., \& Vandekerckhole, T. (2015). Distributed Leadership; Potential \& Implementation through self-managed teams. Sweden: Linnaeus University.

Graeme Knowls. (2011). Quality Management. London; Bookboon.com.

Hardiyansyah. (2011). Kualitas Pelayanan Publik: Konsep, Dimensi, Indikator dan Implementasinya. Yogyakarta: Gava Media.

Haryono, K. (2018). Previous Observation On TO The Service Quality of General Bureau Employee.

Kementerian Sekretariat Negara RI. (2015). Permensesneg Nomor 3 tahun 2015 tentang Organisasi dan Tata Kerja Kemensetneg RI. Jakarta: Kemensetneg RI.

Koutroumanis, D. A., \& Dixon, D. P. (2018). Leadership paradigms, generational differences and cultural norms and their effects on service quality in the restaurant industry. Journal of Business and Entrepreneurship, 29(2), 105-120.

Kuldip Singh. (2016). Influence of Internal Service Quality on Job Performance: A Case Study of Royal Police Department. Procedia; Social and Behavioral Science.

Lukman, S. (2004). Manajemen Kualitas Pelayanan. Jakarta: Sekolah Tinggi Ilmu Administrasi Lembaga Administrasi Negara.

Luthans, F. (2006). Perilaku Organisasi. Yogyakarta: Andi.

Riniwati, H. (2011). Mendongkrak Motivasi dan Kinerja. Malang: Universitas Brawijaya.

Schein, E. H. (2004). Organizational Culture and Leadership ( $3^{\text {rd }}$ ed.). San Francisco: Jossey Bass.

Sedarmayanti. (2013). Manajemen Sumber Daya Manusia; Reformasi Birokrasi dan Manajemen Sumber Daya Manusia (B. R. Aditama (ed.)).

Sutrisno, E. (2011). Budaya Organisasi (II). Jakarta: Kencana Prenada Media Group.

Tjiptono, F. (2008). Service Management: Mewujudkan Pelayanan Prima (2nd ed.). Yogyakarta: Fandi Tjiptono.

In his book, Sampara Lukman stated that the quality of a service is "The service given to customers based on the principles of better service, fast, precise, accurate, friendly according to standardized service standards as guidelines in providing services to customers" (Lukman, 2004). In this opinion, these indicates varied positive guidelines and prioritizing customers' self-satisfaction with the given service.

In corresponding to Atep Adya Barata's opinion, "If an employee is unsatisfied, then you will never gain customer satisfaction" (Barata, 2014). Thus, it is essential to overlook the internal service quality related to the employees' organizational interactions with the accessible facility given on board.

Referring to Zeithamal, Parasuraman and Barry in Graeme Knowls, "Quality in service is divided into 5 dimensions: 1) Tangibles - the service in physical appearance of the surroundings, equipment, staffs and communication flow, 2) Responsiveness - the ability to help the customers at the right time, 3) Reliability - the agility to service in a professional and accurate manner, 4) Assurance - 
knowledge and staff's hospitality as well as their ability to address their trust and confirmation, 5) Empathy - a personal touch and respect." (Graeme Knowls, 2011).

Referring to several concepts about service quality, it could be synthesized that a service quality is an employee activity that related to a professional process of handing a service in order to meet the needs and expectations of a customer in the form of real, professional, mindfulness, assurance and empathy. Their indicators are appearance, amenities, frictionless (real act), accuracy, service standardization, staff's ability (act of being professional), agility, service respond (being mindfulness), being punctual, amenity service and prioritizing customers satisfactions, hospitality and indiscriminate (act of empathy).

Whereas, Edgar Schein stated that a culture is the form of accumulation which must be distributed and grasped by certain association including their behavior, emotions, and cognitive as well as psychological functions in the stated association. (Schein, 2004).

Joanne Martin in Luthans emphasized the perspective differences in many organizations related to the culture of an organization, that is "When an individual connected with an organization, they are connected to the physical appearance, anecdotes, regulation and formal procedures abide by the organization itself, formal behavior code, ritual, tasks, payroll system, language and quirking only understood by inner staff, etc". (Luthans, 2006).

Luthans added that the culture of an organization has several essential characteristics such as the order or regulation of behavior observation, norms, value, philosophy, rules and other benchmarks in the organization (Luthans, et al., 2006). This theory explains the behavior which is a part of a process in interacting each other.

According to Robbins in Edi Sutrisno, there are ten main characteristics that are partially a key role which consists of: 1) member's identity, 2) organization pressure, 3) staffs' objectives, 4) unit integration, 5) control, 6) risk tolerance, 7) appraisal criteria, 8) conflict tolerance, 9) outcome orientation and 10) embracing new system (Sutrisno, et al., 2011).

Meanwhile, Edgar Schein said that there are three phases in an organizational culture: 1) Artifact are stages seen on the surface (consists of all phenomenon which all man can see and hear, 2) Faith, strategic value, aim, philosophy such as freedom and democracy, 3) Basic Assumption, usually insensible, easily accepted, faith, perception, thoughts and feelings, primary assumption will somehow create organization's self-image and how it confronts its surroundings (Schein, et., all 2004).

Based on the several concepts above, it can be concluded that culture in an organization is a system apparatus and the value created are agreed to be the organizational identity in sustaining stability and adapting with the environment based on the dimensions such as identity, value system and controlling system. Those dimensions have indicators such as organization vision and mission indicators, symbols, routine celebration (identity), indicator, faith, norms, orientation, appraisal criteria, precedent guidelines, evaluation, stability and communication scheme (controlling system). 
Conferring to Sedarmayanti, regarding empowerment in general "it felt more empowering than ever before, either in authority, responsibility or the individual's ability" (Sedarmayanti, 2013).

Bawen and Lawler in Gefagnoli defined empowerment as "Sharing with front liners' staff to enhance the organization to become better: information on organizational performance, any slight knowledge for staff to understand and make contributions on organizational performance, rewards based on performance and organizational strength to also make a decision which can affect the organizational performance and it's orientation" (Gefagnoli \& Vandekerckhole, 2015).

According to Newstrom et. Al, empowerment is a sovereignty process and decision making are far bigger for staffs in every factor in affecting work outcomes (Riniwati, 2011).

Khan and Sharafat claimed that "in order to empower workers or staffs, we need to make them acknowledge that they have a full support in decision making, to initiate innovation and or creativity, to communicate and sharing goals, to guide by depicting good samples from top managements. A person who has high confidence and wide knowledge are keen to be empowered" (Gefagnoli \& Vandekerckhole, 2015).

According to Kanter, empowerment could be implemented if a person has few supporting conditions such as access to information, support access, source access, formal strength (strengths are distributed based on the organization chart) and informal strength) (Gefagnoli \& Vandekerckhole, 2015).

In short, the empowerment is somewhat an effort made by an institution to encourage, handover responsibility and partial authority in the aim to expand abilities and self - actualizing of an employee or staff with bearing in mind dimensions of ability, facilitating, teamwork collaboration and guidance. Pointers in empowerment among them are staff guidance, staff training, and opportunities in experiences (capability), information and facilities availability, time management availability, confronting face-to-face, communication (consulting), teamwork pointers between leaders and subordinates, co-worker's collaboration (teamwork encouragement), continuous guidance, financial and moralistic endorsement.

\section{Methodology}

This research was conducted at the General Bureau of the State Secretariat Ministry of Republic of Indonesia, from 2017 to 2019. The research method used is a survey method with a causal approach. Meanwhile, to analyze the effect of one variable with another variable is using the analysis path. This path analysis requires the existence of a significant linear regression relationship between variables. However, to calculate the coefficient of each path, it is necessary to have a correlation coefficient for each of the two variables.

The sample population of this study for the Service Quality variable (Y) were all internal customers of the organization, namely all employees of State Secretariat Ministry other than employee of the General Bureau employees a total of 899 employees. The data analysis unit used as the population for the variables of Organizational Culture (X1), Empowerment (X2) were 307 employees of the General Bureau of the State Secretariat Ministry. To determine the sample, the researcher used the Slovin Formula Technique with proportional random sampling technique. A precision level of $10 \%$ with a confidence level of $90 \%$, the sample obtained for as many as 76 people. 
The questionnaires that have been filled out by the respondents are being calculated using the statistical analysis and assisted by SPPS software version 22, to calculate the normality, linearity and significance tests are carried out before testing the hypothesis.

\section{Research Result}

Testing requirements which include normality, linearity and significance tests are carried out before testing the hypothesis. Based on data processing using SPSS 22, the normality test output is shown in Table 1 below.

Table 1. Normality Data Test Results with Kolmogorov-Smirnov dan Shapiro Wilk

\begin{tabular}{lllll}
\hline No & Regression Model & $\begin{array}{l}\text { Test Statistic } \\
\text { Kolomogorov } \\
\text { Smirnov }\end{array}$ & Conclusion & Interpretasi \\
\hline 1. & $\mathrm{Y}-\mathrm{X} 1$ & 0,216 & $\mathrm{H} 0$ accept & Normal \\
\hline 2. & $\mathrm{Y}-\mathrm{X} 2$ & 0,107 & $\mathrm{H} 0$ accept & Normal \\
\hline 3. & $\mathrm{X} 2-\mathrm{X} 1$ & 0,104 & $\mathrm{H} 0$ accept & Normal \\
\hline
\end{tabular}

From the table above, it shows that the model fulfills the normality assumption by looking at the statistical test score where the sample will be normally distributed if the probability is $>0.05$ then $\mathrm{H} 0$ is accepted, but the population distribution is not normal if the probability then HO is rejected. Furthermore, based on the ANOVA results, it is found that the calculation of $f$ count of Suitable Tuna $<$ Ftable $(\alpha=0.05) 3.97$ is shown in the table:

Table 2. Recapitulation of Linearity Test Results

\begin{tabular}{lllll}
\hline No & Regression Model & F count & F table & Result \\
\hline 1. & Y - X1 & 0,984 & 3,97 & Linier \\
\hline 2. & Y - X2 & 0,589 & 3,97 & Linier \\
\hline 3. & X2 - X1 & 0,961 & 3,97 & Linier \\
\hline
\end{tabular}

Table 3. Recapitulation of Correlation Coefficient Calculation Results

\begin{tabular}{llllll}
\hline No & Regression Model & $\begin{array}{l}\text { Correlation } \\
\text { Coefficient }\end{array}$ & $\mathrm{t}$ count & $\mathrm{t}$ table & Result \\
\hline 1. & $\mathrm{Y}-\mathrm{X} 1$ & 0,687 & 8,142 & 1,992 & Significant \\
\hline 2. & $\mathrm{Y}-\mathrm{X} 2$ & 0,680 & 7,967 & 1,992 & Significant \\
\hline 3. & $\mathrm{X} 2-\mathrm{X} 1$ & 0,771 & 8,709 & 1,992 & Significant \\
\hline
\end{tabular}

From the table above, it is known that $\mathrm{t}$ count $>\mathrm{t}$ table or $\mathrm{H} 0$ is rejected, this means that the correlation between variables is significant. The structural relationship model is tested for the model fit or Goodness of Fit (GOF) model using the LISREL program package. The test was carried out by involving each indicator that forming the variable in the study, namely Organizational Culture / BO (X1)), Empowerment / PB (X2), and Service Quality/KP (Y). 
Table 4. Goodness of Fit (GOF) Table

\begin{tabular}{llll}
\hline Measurement & Score & Description & Conclusion \\
\hline Goodness of Fit Indeks (GFI) & 0,80 & Expected score $>0,80$ & $\begin{array}{l}\text { The model has good } \\
\text { compatibility }\end{array}$ \\
\hline $\begin{array}{l}\text { Root Mean Square Error of } \\
\text { Approximation (RMSEA) }\end{array}$ & 0,046 & Expected score $<0,08$ & $\begin{array}{l}\text { The model has good } \\
\text { compatibility }\end{array}$ \\
\hline
\end{tabular}

The table shows the goodness of the models which consist of various sizes. Based on several measures of model goodness, it can be seen that the model proposed in this study is quite good as seen from the RMSEA value which is within the specified limits. In general, the GFI scores show good results. Thus, it can be said that the model is suitable for use.

Based on the results of the statistical test of structural equation models 1, 2 and 3 obtained, it can be pictured as follows:

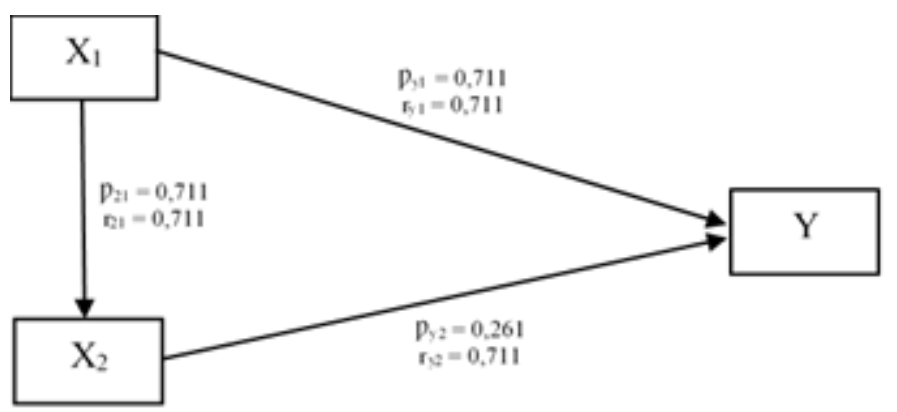

Figure 1. Empirical Model of Structural Relationship between Variables Based on the Results of Path Analysis

In detail, the discussiosn of the results of the analysis and testing of the research hypothesis is explained as follows:

\section{Hypothesis Test Results on the Effects of Organizational Culture (X1) towards the Service Quality} (Y)

Based on the results of the hypothesis test, it shows that organizational culture has a direct effect on service quality by 0.323 or $32.3 \%$. The results of further testing carried out by t-test showed that the $\mathrm{t}-$ count was 2.852 while the $t$-table was $1.992(\alpha=0.05)$, because $t$-count $>t$-table $(\alpha=0.05)$ and the value of sig. $=0.01<\alpha=0.05$, then $\mathrm{H} 0$ is rejected. The results of testing this hypothesis indicate that there is a positive direct effect of Organizational Culture (X1) on Service Quality (Y). The t-test is carried out to confirm that the positive direct effect of organizational culture on service quality is significant.

From the eleven indicators of organizational culture known that there are two indicators that need to be improved, they are the orientation indicator with a score of 4.13. This shows that employees need more support to achieve goals and targets for improvement in the future.

This indicator needs to be improved because it can contribute to the organization in improving service quality. Meanwhile, other indicators such as vision and mission, symbols, routine celebrations, 
beliefs, norms, award criteria, rules, evaluation, stability and communication patterns need to be maintained so that these indicators are well preserved.

Based on empirical evidence, the findings of this study indicate that organizational culture is a very important variable and has a positive direct influence on service quality. This means that the increase of organizational culture will lead to an increase in service quality.

\section{Hypothesis Test Results on the Effects of Empowerment (X2) towards the Service Quality (Y)}

This research hypothesis, shows that empowerment has a direct effect on service quality. As big as 0.261 or $26.1 \%$, with a tcount of 2.215 while ttable of $1.992(\alpha=0.05)$, because tcount $>$ ttable $(\alpha=$ 0.05 ) and sig. $=0.00<\alpha=0.05$, then $\mathrm{H} 0$ is rejected. The results of testing this hypothesis indicate that there is a positive direct influence between empowerment (X2) on service quality (Y). The t-test is carried out to confirm that the positive direct effect of empowerment on service quality is significant.

From the fourteen empowerment indicators, it is known that there is one indicator that needs to be improved, which is the face-view indicator with a score of 4.02. This shows that employees need more face-to-face opportunities in carrying out service tasks and achieving organizational goals.

This indicator needs to be improved because it can contribute to the organization in improving service quality. Meanwhile, other indicators like educating, training, the need for experience, information, facilities, time, communication, leadership and subordinates, guidance, morals and finances should be maintained so that these indicators are well preserved.

Based on empirical evidence, the findings of this study indicate that empowerment is a very important variable and has a direct positive effect on service quality. This means that the increase of empowerment will improve the service quality.

\section{Hypothesis Test Results on the Effect of Organizational Culture (X1) on Empowerment (X2)}

The test results of this hypothesis indicate that Organizational Culture has a direct effect on empowerment by 0.711 or $71.1 \%$, with a tcount of 8,709 , while ttable is $1.992(\alpha=0.05)$, because tcount $>$ ttable $(\alpha=0.05)$ and the sig $=0.012<\alpha=0.05$, then H0 is rejected, which means that Organizational Culture (X1) has a positive direct effect on empowerment (X2). The t-test is carried out to confirm that the positive direct effect of organizational culture on empowerment is significant.

From the eleven indicators of organizational culture, it is known that there are two indicators that need to be improved, namely the orientation indicator with 4.13 score. This shows that employees need support to achieve goals and targets for improvement in the future.

This indicator needs to be improved because it can contribute to the organization in improving service quality. Meanwhile, the other indicators like vision and mission, symbols, routine celebrations, beliefs, norms, award criteria, rules, evaluation, stability and communication patterns need to be maintained so that these indicators are well preserved. 
Based on empirical evidence, the findings of this study indicate that organizational culture is a very important variable and has a positive direct influence on empowerment. This means that the increase of the organizational culture will increase the empowerment.

\section{Hypothesis Test Results on the Effect of Organizational Culture (X1) on Service Quality (Y) through Empowerment (X2)}

In the results of this study using the Sobel Test calculation and obtained a $z$ value of 2.156. Because the $\mathrm{z}$ score obtained is 2.156> 1.96 (absolute $\mathrm{z}$ value) with a significance level of 5\%, it proves that empowerment is able to mediate the influence relationship between organizational culture on the service quality of employees at the General Affair of the State Secretariat.

Based on the results of the hypothesis test, it shows that organizational culture has a direct effect on service quality by 0.323 or $32.3 \%$.

From the eleven indicators of organizational culture, it is known that there are two indicators that need to be improved, namely the orientation indicator with 4.13 score. This shows that employees need support to achieve goals and targets for improvement in the future.

This indicator needs to be improved because it can contribute to the organization in improving service quality. Meanwhile, vision and mission, symbols, routine celebrations, beliefs, norms, award criteria, rules, evaluation, stability and communication patterns need to be maintained so that these indicators are well preserved.

Related to the reality in the field, the researcher argues that even though the organization has procedures and mechanisms for managing empowerment, as stated by the experts above, including in making policies related to empowerment by considering the needs of employees, there are still gaps as seen in the description of the results data. research. Evidence that the Ministry of State Secretariat has empowerment is by holding education and training which are held regularly every year, and employees are given the opportunity to participate.

Based on empirical evidence, the findings of this study indicate that organizational culture affects service quality through empowerment of employees at the General Bureau, the Ministry of State Secretariat. This means that the increase of organizational culture will improve the service quality through empowerment.

\section{Conclusion}

Based on theoretical studies, previous research and data analysis obtained from filling out respondents' research instruments, it can be concluded that: organizational culture has a direct positive effect on service quality, meaning that if the organizational culture increases, it is predicted that service quality will also increase. Empowerment has a positive direct effect on service quality, means that if empowerment increases, it is predicted that service quality will also increase. Organizational culture has a direct positive effect on empowerment, means that if empowerment increases, it is predicted that work attachments will also increase. Service quality has an indirect effect on organizational culture through empowerment, means empowerment is able to mediate the influence of organizational culture on service quality. 
A good and strong organizational culture will create optimal service quality, because all members of the organization have agreed and believe in the values and cultural norms that must be applied in the organization. In addition, employees who have obtained organizational empowerment will have a better experience than before so they will improve their services quality. Organizational culture is also known to affect service quality through empowerment. Commitment from the leaders which is one of element in organizational culture can encourage the achievement of employee empowerment programs so that they can have the appropriate capacity in order to improve the service quality.

\section{Suggestion}

Organizational culture is the most dominant variable that has a direct positive influence on service quality. To improve the service quality, it is necessary to increase organizational culture by socializing and implementing the organization's vision and mission in the daily life of employees which is the biggest indicator of organizational culture.

Empowerment enhancement of the General Bureau can be done by maintaining and improving the implementation of guidance to the employees so it can increase the capacity and responsibility for the services provided.

To improve the service quality, it is necessary to increase the organizational culture through empowerment by internalizing and socializing the organization's vision and mission in the daily lives of employees, through the empowerment by providing the guidance and consultation to all employees so that the service quality can be optimal.

The General Bureau is advised to pay attention to the orientation which is the lowest indicator of the organizational culture variable, by encouraging and providing opportunities for employees to have individual targets in line with organizational targets.

General Bureau can increase empowerment efforts through intensifying face-to-face activities and consultations with employees both with superiors and with colleagues.

The Ministry of State Secretariat can encourage the improvement of the service quality of General Bureau employees by issuing the policies and the regulations that will strengthen organizational culture, empowerment and service quality, such as education and training, career development, crosssectoral collaboration and others.

\section{References}

Barata, A. A. (2014). Dasar-dasar Pelayanan Prima; Persiapan Membangun Budaya Pelayanan Prima untuk Meningkatkan Kepuasan dan Loyalitas Pelanggan. Jakarta: Gramedia.

Bourini, I., Jahmani, A., Mumtaz, R., \& Al-Bourini, F. A. (2019). Investigating the managerial practices' effect on Employee-Perceived Service Quality with the moderating role of supportive leadership behavior. European Research on Management and Business Economics, 25(1), 8-14. https://doi.org/10.1016/j.iedeen.2018.11.001 
Gefagnoli, J., \& Vandekerckhole, T. (2015). Distributed Leadership; Potential \& Implementation through self-managed teams. Sweden: Linnaeus University.

Graeme Knowls. (2011). Quality Management. London; Bookboon.com.

Hardiyansyah. (2011). Kualitas Pelayanan Publik: Konsep, Dimensi, Indikator dan Implementasinya. Yogyakarta: Gava Media.

Haryono, K. (2018). Previous Observation On TO The Service Quality of General Bureau Employee.

Kementerian Sekretariat Negara RI. (2015). Permensesneg Nomor 3 tahun 2015 tentang Organisasi dan Tata Kerja Kemensetneg RI. Jakarta: Kemensetneg RI.

Koutroumanis, D. A., \& Dixon, D. P. (2018). Leadership paradigms, generational differences and cultural norms and their effects on service quality in the restaurant industry. Journal of Business and Entrepreneurship, 29(2), 105-120.

Kuldip Singh. (2016). Influence of Internal Service Quality on Job Performance: A Case Study of Royal Police Department. Procedia; Social and Behavioral Science.

Lukman, S. (2004). Manajemen Kualitas Pelayanan. Jakarta: Sekolah Tinggi Ilmu Administrasi Lembaga Administrasi Negara.

Luthans, F. (2006). Perilaku Organisasi. Yogyakarta: Andi.

Riniwati, H. (2011). Mendongkrak Motivasi dan Kinerja. Malang: Universitas Brawijaya.

Schein, E. H. (2004). Organizational Culture and Leadership ( $3^{\text {rd }}$ ed.). San Francisco: Jossey Bass.

Sedarmayanti. (2013). Manajemen Sumber Daya Manusia; Reformasi Birokrasi dan Manajemen Sumber Daya Manusia (B. R. Aditama (ed.)).

Sutrisno, E. (2011). Budaya Organisasi (II). Jakarta: Kencana Prenada Media Group.

Tjiptono, F. (2008). Service Management: Mewujudkan Pelayanan Prima (2 $2^{\text {nd }}$ ed.). Yogyakarta: Fandi Tjiptono. 